\title{
LOS DERECHOS FUNDAMENTALES COMO LÍMITES EN EL MARCO DE LA INVESTIGACIÓN PRIVADA
}

\author{
M. J JOSEFA RIDAURA MARTÍNEZ \\ Catedrática de Derecho constitucional \\ Universidad de Valencia
}

TRC, n. ${ }^{\circ} 47,2021$, pp. 129-159

ISSN 1139-5583

\section{SUMARIO}

I. Introducción. II. La ordenación jurídica de la investigación privada. III. La función del investigador privado. IV. Derechos fundamentales sobre los que incide la investigación privada. V. El valor probatorio de las pruebas obtenidas por investigadores privados.

\section{INTRODUCCIÓN}

Ciertamente, vivimos en una sociedad hipervigilada que nos convierte, prácticamente, en ciudadanos de cristal; donde no parece quedar sitio alguno para esconderse $^{2}$. Es una vigilancia que se desarrolla en diferentes ámbitos y por diversos agentes, públicos y privados, y, por consiguiente, con objetivos distintos. Desde un punto de vista práctico, esta vigilancia ha sido profundamente transformada por la tecnología. El siglo xx enfrentó a juristas, legisladores y tribunales ${ }^{3}$

1 Trabajo desarrollado en el marco del Proyecto de I+D financiado por el Ministerio de Ciencia, Innovación y Universidades «Seguridad pública, seguridad privada y derechos fundamentales» (Ref. RTI2018-098405-B-100).

2 Bauman, Z. \& Lyon, D.: Vigilancia líquida, Paidós, Buenos Aires, 2013.

3 En esta materia ha sido significativo el constante avance de la legislación sobre el uso de información policial cuyo último hito es la Directiva (UE) 2016/680 del Parlamento Europeo y del Consejo, de 27 de abril de 2016, relativa a la protección de las personas físicas en lo que respecta al tratamiento de datos personales por parte de las autoridades competentes para fines de prevención, investigación, detección o enjuiciamiento de infracciones penales o de ejecución de sanciones penales, y a la libre circulación de dichos datos y por la que se deroga la Decisión Marco 2008/977/JAI del Consejo. D.O.U.E., serie L, n. ${ }^{\circ}$ 119, de 4 de mayo de 2016, pp. 89 y ss. Así como las posiciones del TJUE en relación con el acceso a datos de comunicaciones en Digital 
al reto de preservar nuestros derechos ante los avances de la tecnología. Desde la década de los ochenta del pasado siglo la aceleración de la tecnología ha revolucionado las posibilidades de la hipervigilancia definiendo un escenario de vigilancia líquida, en palabras de Bauman, con herramientas muy variadas. Las cámaras se miniaturizan al tiempo que ganan en calidad, la tecnología denominada internet de los objetos multiplica los sensores y la posibilidad de trazar prácticamente cualquier persona o cosa, los servicios de inteligencia pueden intervenir teléfonos móviles, ordenadores, tabletas o televisiones inteligentes y activar remotamente sus micros y cámaras, la analítica de datos alimenta sistemas de inteligencia artificial usados por la policía para definir prioridades de actuación ${ }^{4}$, la geolocalización ubica permanente a cualquier persona en cualquier espacio, entre otros ejemplos.

Aun así, es más factible saber, aunque no con toda precisión, cómo nos investigan los poderes públicos en el ejercicio de sus funciones; por ejemplo, en aquellas que exigen una labor de comprobación por parte de la Agencia Tributaria en desarrollo del cumplimiento del deber constitucional de contribuir al sostenimiento de los gastos públicos (artículo $31 \mathrm{CE}$ ); o de la desarrollada por las entidades prestadoras de servicios y prestaciones públicas en orden a determinar la licitud de su percepción. En este sentido, constituyen ejemplos paradigmáticos las previsiones legales para la investigación del blanqueo de capitales que comportan cesiones obligatorias de datos personales, o el uso de drones para indagar construcciones ilegales por la Agencia Estatal de Administración Tributaria. Y, señaladamente, la investigación criminal encomendada constitucionalmente a la Policía Judicial en sus funciones de averiguación del delito y descubrimiento y aseguramiento del delincuente (artículo 126); siempre bajo la dependencia de Jueces, Tribunales y Ministerio Fiscal ${ }^{5}$. Aunque son las exigencias de Seguridad las que habilitan a Fuerzas y Cuerpos de Seguridad y a las Agencias de Inteligencia — en aras de la Seguridad Nacional - a realizar funciones de vigilancia cada vez más expansivas; sobre todo en el marco de la lucha antiterrorista. Vigilancia que se produce tanto en el marco nacional como en el internacional ${ }^{6}$; si bien en este último las garantías son más débiles y difusas, facilitándose, incluso, la investigación extraterritorial.

Estamos, pues, ante una vigilancia «pública» muy intensa; pero que no acaba ahí; pues el ordenamiento jurídico permite, también, la vigilancia por parte de los

Rights Ireland Ltd (asunto C-293/12) y los dos casos Schrems en los asuntos C-362/14 (Safe Harbour) y C-311/18 (Privacy Shield).

4 Vid. Martínez Martínez, R.: «Inteligencia artificial, Derecho y derechos fundamentales», Sociedad Digital y Derecho, De La Quadra-Salcedo y Fernández Del Castillo, T. (dirs.), Piñar Mañas, J.L. (aut.), 2018, pp. 259-278.

5 El Estado mantiene el monopolio en la investigación de los delitos públicos, y se descarta la posibilidad de indagaciones paralelas a las que puedan estar realizando la autoridad judicial o las fuerzas de seguridad del estado en relación con los mismos (Sentencia del Tribunal Supremo 419/1992, de 13 de julio).

6 Vid. Serra Cristobal, R.: La Seguridad como amenaza. Los desafíos de la lucha contra el terrorismo para el Estado democrático, Tirant lo Blanch, Valencia, 2020. 
agentes privados; que suele presentarse como más ambigua que la anterior; rodeada, casi siempre, de un cierto halo espinoso, suspicaz y desconfiado. Es una investigación que tiene por objeto la obtención de información y pruebas sobre conductas o hechos privados; cuyo basamento es distinto a la investigación pública, y que va mucho más allá del seguimiento y captación de imágenes como medio de prueba en casos de conflictos conyugales. Su campo de actuación es variado y, además, sus servicios son cada vez más demandados; sobre todo, en el ámbito laboral en el que con mayor frecuencia se recurre a la contratación de detectives para esclarecer casos de absentismo laboral, espionaje industrial, o competencia desleal, entre otros. La investigación privada alcanza a otras muchas esferas como, por ejemplo, los conflictos de custodia de menores y de abono de pensiones de paternidad, comportamientos de los hijos, averiguación de ludopatías, información económica y financiera solicitada por las entidades de crédito, quiebras, suspensiones de pago, localización de propiedades; y también la contratación de estos servicios por mutuas y compañías aseguradoras para averiguar las bajas simuladas o las incapacidades, también simuladas, en casos de accidentes. Estos son sólo algunos de los ejemplos, que pueden situarse, más bien, en un espacio privado, aunque tengan repercusiones de calado.

Pero, son, asimismo, conocidas las investigaciones privadas que trascienden el ámbito meramente privado, alcanzando auténtica relevancia pública. Baste recordar, ahora, la revelación de la operación Malaya — de corrupción urbanística en Marbella-, y, por lo tanto, de repercusión política; el origen de parte de los documentos que incriminaban al expresidente de la Generalitat de Cataluña Jordi Pujol y su familia; así como los seguimientos, escuchas, y grabaciones a dirigentes políticos.

Esta investigación privada es la que vamos a abordar en este trabajo, en el que nos proponemos indagar sobre cómo nos pueden investigar y como nos investigan, realmente, los agentes privados de investigación; esto es, los detectives profesionales. Afrontaremos cómo puede realizarse dicha investigación, a quién puede ir dirigida, cómo ha de obtenerse, y, en último término, que alcance puede tener; esto es, cuáles pueden ser sus consecuencias, y qué valor probatorio pueden tener sus informes. Todo ello con el propósito de enmarcar la actuación de los detectives privados en las exigencias derivadas del texto constitucional de respeto de los derechos fundamentales. Tema ayuno de tratamiento doctrinal desde el Derecho Constitucional $^{7}$, cuyo ineludible estudio reside en la necesidad de anclar la actuación de la investigación privada en dichas exigencias constitucionales, partiendo de la eficacia no sólo vertical, sino también horizontal de los derechos. Precisamente, porque el constitucionalismo moderno supera la clásica — como

7 Pascual Medrano, A.: «Detectives privados y protección de derechos fundamentales: una delicada relación», Diario La Ley, n. ${ }^{\circ} 8193,18$ noviembre, de 2013. Ridaura MArTinez, M. ${ }^{a}$ J.: Seguridad Privada y Derechos Fundamentales (La nueva Ley 5/2014, de 4 de abril, de Seguridad Privada), Tirant lo Blanch, Valencia, 2015 . 
diría Pace ${ }^{8}$ - separación Estado-sociedad, característica de la teoría estatalista de los derechos públicos subjetivos, y se centra en limitar el poder político, pero también el privado.

Enmarcamos, así, este estudio partiendo de la centralidad de los derechos fundamentales como elementos identificadores de la supremacía constitucional, y, por ende, del Estado constitucional; pues como afirma Fioravanti «lo que distingue a un Estado constitucional es la institución de un «espacio de derechos»"; de unos derechos fundamentales que pasan a convertirse en ejes vertebradores de todo el ordenamiento ${ }^{10} \mathrm{y}$, en consecuencia, no pueden quedar espacios ajenos a los mismos, ni en la actuación de los poderes públicos, ni en la de los particulares.

\section{LA ORDENACIÓN JURÍDICA DE LA INVESTIGACIÓN PRIVADA}

Es la Ley de Seguridad Privada la que ordena jurídicamente la profesión del investigador privado; pese a que su función sólo coincida con dicha norma en el adjetivo. Y es que su ordenación se corresponde con una historia de desaciertos, caracterizada por la dispersión y la inseguridad, desembocando, incluso, en la declaración de inconstitucionalidad. Y, aunque no es el propósito de este trabajo analizar la ordenación jurídica de los detectives privados, nos referiremos a ella para determinar su marco de su actuación en el desempeño de sus funciones y su incidencia sobre los derechos fundamentales.

Inicialmente, la función de los detectives se reguló por Órdenes ministeriales. Su primera ordenación jurídica se remonta a la Orden de 14 de enero de 1951 por la que se reglamentan las actividades de investigación de las llamadas «Agencias Privadas de Investigación»; que se modificó por la Orden de 7 de marzo de 1972, y con posterioridad por la Orden del Ministerio del Interior de 20 de enero de $1981^{11}$, regulando con más detenimiento los requisitos y condiciones de ejercicio de la profesión; el sistema de intervención o control de la Administración del Estado en la organización, puesta en marcha y funcionamiento de las agencias privadas de investigación; e inclusive el régimen sancionador aplicable a los titulares de las agencias y al personal vinculado a las mismas; confiriendo la competencia a la Dirección General de Seguridad en Madrid y a los Gobernadores civiles para autorizar estas actividades de investigación. Orden que fue considerada por el Tribunal

8 PACE, A.: «Los retos del constitucionalismo del siglo XXI», RDCE, n. ${ }^{\circ}$ 2, 2004.

9 Fioravanti M.: Constitucionalismo. Experiencias históricas y tendencias actuales, Trotta, 2014; Así como la obra de referencia de López Guerra, L.M.: Introducción al Derecho Constitucional, Tirant lo Blanch, Valencia, 1994.

10 Vid. esta evolución en CRuZ Villalon, P.: «Formación y evolución de los derechos fundamentales», REDC, n. ${ }^{\circ} 25,1989$, pp. 35 y ss.

11 STC 61/1990, de 29 de marzo, declaró la nulidad del art. 12 de dicha Orden por considerar que era carente de cobertura legal mínima. 
Constitucional carente de cobertura legal mínima, ya que las sanciones que preveía no satisfacían la exigencia del artículo 25.1 CE, ni en su aspecto formal, ni en el material o sustantivo.

La primera norma con rango de ley que ordenó esta actividad fue la Ley 23/1992, de 30 de julio, de Seguridad Privada; que nació para acomodar la seguridad privada al texto constitucional, tratando de paliar las deficiencias de las normas reguladoras de este sector existentes hasta el momento: disposiciones preconstitucionales desfasadas y caracterizadas por su enorme dispersión, generando importantes lagunas, abocando a actuaciones que tenían, en ocasiones, una débil cobertura legal, en otras ni siquiera así. La inclusión de los investigadores privados en esta ley se justificó por la necesidad de resolver los problemas que planteaba su deficiente normativa; de tal forma que la propia Exposición de Motivos de la Ley la fundamentaba en razones tanto de urgencia, como de oportunidad para resolver los problemas de la profesión. Recuérdese que la STC 61/990, de 29 de marzo había advertido, al declarar inconstitucional, y, por tanto, nulo el precepto que regulaba el régimen sancionador, del vacío normativo que ello provocaba y, en consecuencia, de la necesidad de que los poderes públicos actuaran con celeridad aprobando una norma con rango de ley. Si bien, aunque la Ley 23/1992 les incluía, no los confundía, ya que nos los equiparaba con las funciones de seguridad (privada).

La nueva Ley 5/2014, de 14 de abril, de Seguridad Privada (en adelante LSP) integra también a los detectives, pero, a diferencia de la ley del 92, les equipara con los agentes de seguridad privada. Y, pese a que el Preámbulo de la Ley parte de que los servicios de vigilancia son diferentes de los demás servicios de seguridad privada, afirma que «su acogida en esta norma, dentro del conjunto de actividades de seguridad privada, refleja la configuración de aquéllos como un elemento más que contribuye a garantizar la seguridad de los ciudadanos, entendida en un sentido amplio». Afirmación que nos parece cuestionable.

Ciertamente, constituye una exigencia la ordenación jurídica de la actividad de investigación privada; señaladamente, por la plena incidencia de sus funciones en la esfera de determinados derechos fundamentales que son nucleares, y, de hecho, la nueva norma intensifica los controles sobre la actividad de los detectives privados, con nuevas obligaciones, y un fortalecimiento del deber de reserva profesional. Pero, dicha ordenación, ni por su ámbito de actuación, ni por las funciones que tienen encomendadas los detectives, justifica un régimen jurídico equiparable al de los agentes de seguridad. Y es que debemos partir de la distinta naturaleza de las funciones de seguridad y las de investigación; esto es, la función de los primeros se centra exclusivamente en la preservación de la seguridad; privada, pero seguridad. Sin embargo, la función de los detectives privados es de investigación — privada_-; aunque muy tangencialmente podrían converger, quedando restringida a la obtención de información privada sobre hechos privados, como veremos a continuación. La función del investigador privado está dirigida a obtener información, no a contribuir a la seguridad; de ahí el error de la 
Ley al incluirlos en un mismo texto y equipararlos. Además, los derechos sobre los que pueden incidir las funciones de unos y otros son, también, distintos; por tanto, su cabal tratamiento requeriría una norma individualizada ${ }^{12}$.

La dificultad de la inadecuada ordenación jurídica se agrava, además, por la ausencia de Reglamento de desarrollo, ya que — a día de hoy- la ley del año 2015 sigue acompañada del Real Decreto 2364/1994, de 9 de diciembre, por el que se aprueba el Reglamento de Seguridad Privada; el proyecto de reglamento lleva todos estos años atascado.

\section{LA FUNCIÓN DEL INVESTIGADOR PRIVADO}

Para adentrarnos en el objeto de nuestro trabajo debemos plantearnos, en primer término, qué información puede buscar un detective y cómo puede obtenerla.

Los servicios de investigación privada, a cargo de detectives privados, se centran en la realización de las averiguaciones necesarias para la obtención de información y aportación de pruebas sobre conductas o hechos privados por cuenta de terceros legitimados, mediante la realización de averiguaciones en relación con personas, hechos y conductas privadas (artículo 37 LSP), concretando dicha información en relación con los siguientes aspectos:

a) Los relativos al ámbito económico, laboral, mercantil, financiero y, en general, a la vida personal, familiar o social, exceptuada la que se desarrolle en los domicilios o lugares reservados. Sus investigaciones encuentran nichos importantes; particularmente, el laboral está cobrando cada vez mayor protagonismo; pero también otros, como hemos apuntado anteriormente. Y además de los que hemos adelantado en la introducción, el espionaje industrial, o a personajes o empresarios de relieve, incluso el espionaje contratado por partidos políticos e, incluso, por instituciones públicas.

b) La realización de averiguaciones y la obtención de información y pruebas relativas a delitos sólo perseguibles a instancia de parte por encargo de los sujetos legitimados en el proceso penal. Y es que, si bien la investigación penal está reservada a la Policía Judicial, por lo que los detectives no podrán realizar investigaciones sobre delitos perseguibles de oficio; debiendo denunciar inmediatamente ante la autoridad competente cualquier hecho de esta naturaleza que llegara a su conocimiento y poniendo a su disposición toda la información y los instrumentos que

12 Así se ha venido advirtiendo por los integrantes del sector, postulando una norma propia, vid. Gutiérrez Gutiérrez, A.: «Aspectos jurídicos de la investigación privada», Quadernos de Criminología: Revista de criminología y ciencias forenses, n. ${ }^{\circ}$ 7, 2009, pp. 14-21. 
pudieran haber obtenido ${ }^{13}$. Pero sí que es posible que el investigador privado pueda desarrollar su función en este ámbito, aunque sólo en delitos perseguibles a instancia de parte, esto es: delitos contra el honor, intimidad y descubrimiento y revelación de secretos; abandono de familia e impago de pensiones; delitos de daños imprudentes, delitos relativos al mercado y a los consumidores, delitos societarios, delitos contra la indemnidad sexual (agresiones, abusos y acoso); y delito de reproducción asistida no consentida ${ }^{14}$.

Además, la LSP (artículo 48) contempla una función de obtención de información tendente a garantizar el normal desarrollo de las actividades que tengan lugar en ferias, hoteles, exposiciones, espectáculos, certámenes, convenciones, grandes superficies comerciales, locales públicos de gran concurrencia o ámbitos análogos; que sería la que podría confluir con la de seguridad; tal y como hemos advertido con anterioridad.

La información recabada por un investigador privado ha de obtenerse en el marco de diversas exigencias:

I. Por un lado, constitucionales, pues también los particulares están vinculados por los derechos ${ }^{15}$. Hoy en día, los derechos ya no son sólo limitaciones de las atribuciones de las autoridades o simples derechos públicos subjetivos. Los derechos no son sólo derechos frente a los poderes públicos; son derechos frente a todos, y frente a todo poder: público y privado. En consecuencia, la eficacia de los derechos frente a terceros es incuestionable. Es verdad que desde otras posiciones se ha llegado a negar tal vinculación, partiendo de que en la esfera de las relaciones entre privados rige el principio de autonomía de la voluntad, limitándose los mandatos constitucionales a los poderes públicos. Esta concepción no puede sostenerse en el constitucionalismo actual, pues, de acuerdo con el artículo 9.1 $\mathrm{CE}$, «los ciudadanos y los poderes públicos están sujetos a la Constitución y al resto del ordenamiento jurídico». Por tanto, siendo los derechos fundamentales la piedra angular de nuestro ordenamiento constitucional, también éstos vinculan a los ciudadanos; influyendo no solo, como afirma

13 De forma que el art. 25 LSP recoge entre las obligaciones de los detectives «facilitar de forma inmediata a la autoridad judicial o a las Fuerzas y Cuerpos de Seguridad competentes las informaciones sobre hechos delictivos de que tuvieren conocimiento en relación con su trabajo o con las investigaciones que éstos estén llevando a cabo». El estado mantiene el monopolio en la investigación de los delitos públicos, y se descarta la posibilidad de indagaciones paralelas a las que puedan estar realizando la autoridad judicial o las fuerzas de seguridad del estado en relación con los mismos (STS 419/1992, de 13 de julio).

14 Almodovar Puig, B.: Delitos perseguibles a instancia de parte, Aranzadi, 2016.

15 Bilbao Ubillos, J.M.: La eficacia de los derechos frente a particulares, CEPC, Madrid, 1997 y GUTIERREZ GutiérReZ, I.: «Criterios de eficacia de los derechos fundamentales en las relaciones entre particulares», Teoría y Realidad Constitucional, n. ${ }^{\circ}$ 3, 1999, pp. 193-211. 
Konrad Hesse, en las relaciones jurídicas de los ciudadanos con los poderes públicos, sino también en las relaciones jurídicas entre los particulares $^{16}$. La diferente vinculación se concreta en que los poderes públicos están vinculados tanto positiva como negativamente; mientras que en el caso de los particulares la vinculación es negativa, en cuanto que no pueden vulnerar los derechos fundamentales. Y, puesto que los detectives no tienen la consideración de agentes de la autoridad, dicha vinculación opera negativamente; pero opera. El detective ejerce una actividad profesional habilitado por el Ministerio de Interior $^{17}$, pero no es agente de la autoridad $^{18}$.

La LSP no reconoce la condición de agentes de autoridad al personal de seguridad privada ${ }^{19}$; tan sólo se les confiere protección penal en relación con las agresiones y desobediencias de las que sean objeto cuando desarrollen actividades de seguridad privada en cooperación y bajo el mando de las Fuerzas y Cuerpos de Seguridad. Esta es una previsión pensada para los demás agentes de seguridad contemplados en la ley, que sí que realizan funciones de seguridad. Pero no creemos que dicha protección pueda extenderse a los detectives, ya que ellos no realizan dichas actividades; y ello por mucho que el legislador se haya empeñado en incluirlos en la ley y equipararlos. Y, aunque el articulo 37 LSP prevé la necesaria colaboración con las Fuerzas y Cuerpos de Seguridad cuando sus actuaciones profesionales se encuentren relacionadas con hechos delictivos o que puedan afectar a la seguridad ciudadana, se trata más bien de un deber de información que no alcanza a conferirles la protección como agentes de la autoridad; o bien de una colaboración puntual, en determinados casos. La relación que tienen los detectives con Fueras y Cuerpos de Seguridad lo es más a efectos de control, como veremos más tarde.

16 Hesse, Konrad, «Significado de los derechos fundamentales», Benda, E; Mainofer, W.; Vogel, Hesse, K.; Heyde, W.: Manual de Derecho Constitucional (Trad. A. López Pina), Marcial Pons, Madrid, 1996.

17 Requiriendo, hoy en día, estar en posesión de un título universitario oficial de grado en el ámbito de la investigación privada que acredite la adquisición de las competencias que se determinen, o bien del título del curso de investigación privada, reconocido por el Ministerio del Interior.

18 Un estudio pormenorizado del tema en Villalba López, N.: «Conductas típicas en el delito de atentado contra el personal de Seguridad privada: algunas propuestas para su interpretación», Revista de Derecho Penal y Criminología, n. 19/2018, pp. 179-228.

19 Esta consideración como agentes de la autoridad era una de las pretensiones largamente demandadas por el sector a lo largo de la historia de la seguridad privada. Y si bien El Tribunal Supremo, reconoció durante muchos años la condición de Agentes de la Autoridad a los Guardas jurados, defendiendo la atribución de la defensa y protección de las personas y de las propiedades, en el entorno de la investigación delictiva, a los Vigilantes Jurados de Seguridad, al menos como auxiliares de la Policía Judicial, tal y como se establecía en el art. 283.6. ${ }^{\circ}$ LeCrim (que los incluía entre los componentes de la Policía Judicial cuando estuvieran confirmados por la Administración). Manteniendo, por tanto, el carácter y calidad de Agentes de la Autoridad cuando estuvieran en el ejercicio del cargo vistiendo el uniforme, tal y como se establecía en la legislación preconstitucional. Pero, años más tarde, el propio Tribunal Supremo dará un giro radical, negando el carácter de Agentes de la Autoridad a los vigilantes jurados. Pero, nunca ha sido reclamada dicha condición por parte de los detectives. 
II. Por otro lado, la búsqueda y obtención de investigación está sujeta a exigencias legales, que vienen a ser, en la mayoría de los casos, proyecciones de las constitucionales. Y, en este sentido, la LSP regula una serie de exigencias y controles, pues, en atención a la naturaleza de las funciones de los detectives, se les exige especial cautela:

a) Sujetando los servicios de investigación privada al respeto a los principios de razonabilidad, necesidad, idoneidad y proporcionalidad (artículo 48.6); exigencia que deriva de la doctrina constitucional, aplicable a toda actuación que afecte a los derechos.

b) La habilitación legal de los detectives no es absoluta, ya que encuentra como límite, infranqueable, el contenido esencial de los derechos fundamentales, pues en ningún caso podrán utilizar para sus investigaciones medios materiales o técnicos que atenten contra el derecho al honor, a la intimidad personal o familiar o a la propia imagen o al secreto de las comunicaciones ${ }^{20}$ (más adelante nos detendremos en ello), considerando la LSP su utilización como infracción muy grave, siempre que no constituyan delito (artículo 48.3).

Si bien, en este ámbito se abren nuevos escenarios, pues también las nuevas tecnologías son utilizadas - y en gran medida - en este tipo de investigación: las micro cámaras escondidas en botones, o todo un arsenal de artilugios tecnológicos para la investigación, que facilitan la toma sistemática de imágenes, o grabaciones, sin que la persona afectada pueda percatarse de ello. El aprendizaje de la neurociencia aplicada al marketing que abre el campo a la analítica del comportamiento en redes sociales para los servicios de investigación privada, por ejemplo, en el ámbito de la contratación de cargos directivos; técnicas de reconocimiento facial en caso de búsqueda de personas desaparecida; el barrido electrónico para localizar sistemas de grabación ocultos, etc, que requieren una mayor especialización. Los grandes despachos de detectives cuentan con expertos en nuevas tecnologías como ingenieros informáticos y otros profesionales aptos para el manejo de todas estas herramientas orientadas a la investigación.

$\mathrm{Y}$, siendo o no conscientes, la huella digital que dejamos es fácilmente rastreable, de modo que, en muchas ocasiones, como indican los profesionales, «Solo con lo que encontramos en Internet, resolvemos casi la mitad del asunto...La gente nos lo pone fácil». Y es que, tanto el uso que hacemos de internet, como de la telefonía móvil, por ejemplo,

20 Pues, como advierte Gutiérrez Gutiérrez, A., «en el ejercicio de la profesión de detective privado, la línea que separa lo lícito de lo ilícito es muy fina», «Aspectos jurídicos de la investigación privada», Quadernos de Criminología: Revista de criminología y ciencias forenses, n. ${ }^{\circ}$ 7, 2009, p. 18 
nos hace permanentemente visibles. «Tenemos una flecha de neón parpadeante sobre nuestras cabezas» ${ }^{21}$.

c) La LSP (artículo 48.2) establece como requisito para la aceptación del encargo de los servicios de los despachos de detectives, la acreditación, por el solicitante de los mismos de un interés legítimo alegado, debiendo dejar constancia de ello en el expediente de contratación e investigación. Considerándose, falta muy grave la realización de investigaciones privadas a favor de solicitantes en los que no concurra un interés legítimo en el asunto.

Siendo un concepto jurídico indeterminado, podemos plantearnos cómo ha de interpretarse y, en consecuencia, cuándo existe ese el interés legítimo. Podemos reconducirlo, en la esfera privada en la que nos estamos moviendo, a un interés jurídicamente protegido. $Y$, por ejemplo, puede alegar un interés legítimo el empresario en atención a sus funciones de control; también lo hay cuando se trata de determinar el cobro indebido de prestaciones. En algunos casos, la protección de dicho interés por el derecho es fácilmente apreciable. Pero, en otros casos los contornos son más difíciles de fijar: por ejemplo, ¿puede contratarse los servicios de un detective para investigar con carácter previo a alguien antes de ser contratado? En el momento de la contratación corresponde al profesional valorar si existe o no dicho interés; pero, a posteriori, será un control judicial el que determine si ese interés que puso en marcha una investigación ya realizada era legítimo o no.

d) La Ley del 2014 intensifica los controles sobre la actividad de los detectives privados; quizás esta fue una de las principales razones de elaboración de la nueva norma ${ }^{22}$. Por un lado, las investigaciones privadas, que tienen carácter reservado, puedan conocerse, también, por los órganos judiciales y policiales; en este último supuesto únicamente para una investigación policial o para un procedimiento sancionador (artículo 50 LSP).

Por otro lado, se requiere la realización de un informe con los datos de la persona que encarga y contrata el servicio, el objeto de la contratación, los medios, los resultados, los detectives intervinientes y las actuaciones realizadas ${ }^{23}$. Informe que no sólo está a disposición del cliente, sino también de las autoridades policiales

21 «Los detectives lo tenemos más fácil que nunca», El País (13.05.2017).

22 Controles que, en parte, han sido bien recibidos por integrantes del sector, ya que, incluso, pueden poner coto a las cifras algo elevadas de intrusismo profesional. Además, detrás de todos estos controles se esconde la sombra de escándalos como el de las escuchas que se atribuyeron a Método 3, así como las prácticas perniciosas de algún ex comisario de renombre.

23 Aunque, en el informe de investigación únicamente se hará constar información directamente relacionada con el objeto y finalidad de la investigación contratada, sin incluir en él referencias, informaciones o datos que hayan podido averiguarse relativos al cliente o al sujeto investigado, en particular los de carácter 
competentes para la inspección, pudiendo tenerse acceso al contenido por requerimiento judicial o solicitud policial relacionada con el ejercicio de sus funciones en el curso de una investigación criminal o de un procedimiento sancionador ${ }^{24}$.

$\mathrm{Y}$ es que —en este y en otros muchos casos — la legislación suele constituir una respuesta a los excesos; por lo que las medidas van dirigidas a prevenir o sancionar la anormalidad, pero se aplica por igual a toda actuación, derivando, en ocasiones, en medidas que pueden ser desproporcionadas. Sin ambages es exigible la sujeción de las actuaciones de la investigación privada a controles que aseguren su plena adecuación al ordenamiento, especialmente para asegurar el respeto a los derechos fundamentales. Sin embargo, las previsiones de la ley en orden al Informe del detective nos plantean una serie de interrogantes, ya que éste puede estar a disposición de las autoridades policiales para la inspección ${ }^{25}$; lo que implica que la policía puede entrar a conocer al contenido de las investigaciones cuando se trata de investigación policial o en relación con un expediente sancionador, sin que medie intervención judicial.

Este conocimiento del contenido del Informe sin intervención judicial puede, por un lado, disuadir a un cliente para la contratación de un servicio, si sabe que sus datos pueden llegar, sin dicha intervención judicial, a las autoridades policiales. Y, por otro lado, puede colisionar con los intereses de los clientes que pueden ver afectados; así como con el secreto profesional que cubre al investigador privado, ya que dicho deber de secreto se establece, no en beneficio del profesional, sino de la persona que le ha confiado esos hechos o esas confidencias. Pudiendo incurrir, incluso en el delito contemplado en el artículo 199.1 del Código Penal que tipifica como delito la revelación de secretos ajenos, de los que tenga conocimiento por razón de su oficio o sus relaciones laborales.

Si realmente el propósito del legislador es reforzar la obligación del detective de poner en conocimiento de la autoridad competente cualquier hecho constitutivo de un delito perseguible de oficio (cuya investigación les está vetada) cuando llegara a su conocimiento; debiendo poner a su disposición toda la información y los instrumentos que pudieran haber obtenido hasta ese momento, relacionado con dichos delitos, dicha obligación ya se incluye en el artículo 10.2 de la LSP. Reforzándose, además, en el artículo 262 LeCrim cuando establece la obligación de quienes por razón de sus cargos, profesiones u oficios tuvieren noticia de algún

personal especialmente protegidos, que no resulten necesarios o que no guarden directa relación con dicho objeto y finalidad ni con el interés legítimo alegado para la contratación (art. 49.2 LSP).

24 Las actuaciones se limitarán a la comprobación de su existencia, sin entrar en su contenido, salvo que se encuentre relacionado con una investigación judicial o policial o con un expediente sancionador. Estas cautelas, seguramente, responden a la desaparición o destrucción de informes, que se ha producido en alguna ocasión, sin causa justificada.

25 Que deberá tener especial cautela en relación con las imágenes, sonidos o datos personales obtenidos que obren en el expediente de investigación; «en cuyo caso las actuaciones se limitarán a la comprobación de su existencia, sin entrar en su contenido, salvo que se encuentre relacionado con una investigación judicial o policial o con un expediente sancionador». 
delito público de denunciarlo inmediatamente al Ministerio fiscal, al Tribunal competente, al Juez de instrucción y, en su defecto, al municipal o al funcionario de policía más próximo al sitio si se tratare de un delito flagrante.

Y, en último término, la obtención de la investigación ha de realizarse respetando los derechos, pues la licitud de la obtención de la información está anudada al valor probatorio de las pruebas obtenidas, ya que tal y como establece el artículo 11. 1. de la LOPJ: «No surtirán efecto las pruebas obtenidas, directa o indirectamente, violentando los derechos o libertades fundamentales»; recogiendo, así, el precepto la doctrina anglosajona de la «la fruta del árbol envenenado», de modo que el juez no puede valorar ni las pruebas obtenidas con violación de un derecho fundamental, ni las que deriven de aquélla ${ }^{26}$. Tema al que nos referiremos posteriormente.

\section{DERECHOS FUNDAMENTALES SOBRE LOS QUE INCIDE LA INVESTIGACIÓN PRIVADA}

Especialmente, la labor de investigación privada incide sobre los derechos fundamentales que protegen la esfera privada. Por esta razón, el artículo 48.3 LSP contempla, expresamente, que «En ningún caso se podrá investigar la vida íntima de las personas que transcurra en sus domicilios u otros lugares reservados, ni podrán utilizarse en este tipo de servicios medios personales, materiales o técnicos de tal forma que atenten contra el derecho al honor, a la intimidad personal o familiar o a la propia imagen o al secreto de las comunicaciones o a la protección de datos». Ciertamente, estos son derechos que pueden verse afectados por la investigación privada; sin embargo, no son los únicos, como podremos comprobar a continuación.

\section{La protección del domicilio constitucional}

Contamos con una acrisolada doctrina constitucional que ha considerado que la inviolabilidad del domicilio garantiza un ámbito de privacidad, dentro del espacio limitado que la propia persona elige y que tiene que caracterizarse precisamente por quedar exento o inmune a las invasiones o agresiones exteriores, de otras personas o de la autoridad pública. Es, pues el espacio en el que la persona ejerce su libertad más íntima ${ }^{27}$. Y protege, pues tanto frente poderes públicos, como frente a particulares.

26 SSTC 98/2000, de 10 de abril; 186/2000, de 10 de julio; 29/2013, de 11 de febrero; y 39/2016, de 3 de marzo.

27 STC 22/1984, de 17 de febrero en la que aclara el concepto constitucional de domicilio confiriéndole una protección de carácter instrumental, que defiende los ámbitos en que se desarrolla la vida privada de 
Ciertamente, un investigador privado no tiene la posibilidad de entrar en el domicilio ajeno ni por flagrancia del delito, ni tampoco mediante autorización judicial, pues no es un agente de la autoridad. La única posibilidad para que no se produjera en caso de entrada un allanamiento de morada ${ }^{28}$ sería la autorización del titular. Es particularmente interesante a este respecto la Sentencia ${ }^{29}$ que condena como responsable de un delito contra la intimidad del artículo 197. 1 del Código Penal, a una detective contratada por una empresa con el objeto de realizar una investigación, sospechando que la trabajadora estando de baja realizaba en su domicilio otras actividades retribuidas. En este marco la detective entró en el domicilio de la demandante y sin ninguna autorización, ni de la titular del domicilio ni judicial, procedió a grabar con cámara oculta en el interior del mismo.

Sólo las Fuerzas y Cuerpos de Seguridad están habilitadas para la entrada en el domicilio de acuerdo con los supuestos previstos constitucionalmente (art. 18.2), y desarrollados por la Ley Orgánica de Seguridad Ciudadana (art. 15), que los extiende — como causa legítima suficiente para la entrada en domiciliopor la necesidad de evitar daños inminentes y graves a las personas y a las cosas, en supuestos de catástrofe, calamidad, ruina inminente u otros semejantes de extrema y urgente necesidad; esto es, el conocido periculum in mora, o estado de necesidad. O bien, los miembros del Centro Nacional de Inteligencia, cuya entrada en el domicilio requiere la autorización y supervisión judicial ${ }^{30}$.

$\mathrm{Ni}$ siquiera podría confundirse - y conviene aclararlo- la figura del detective con la del agente encubierto ${ }^{31}$. No guardan ninguna relación. El primero previsto en el artículo 282 bis de la Ley de Enjuiciamiento Criminal (en adelante LeCrim) sólo cabe en las investigaciones que afecten a actividades propias de la

la persona. «Por ello existe un nexo de unión indisoluble entre la norma que prohíbe la entrada y el registro en un domicilio (art. 18.2 CE.) y la que impone la defensa y garantía del ámbito de privacidad (art. 18.1 CE). Todo ello obliga a mantener, por lo menos «prima facie», un concepto constitucional de domicilio de mayor amplitud que el concepto jurídico privado o jurídico-administrativo». El rasgo esencial que define el domicilio a los efectos de la protección dispensada por el art. 18.2 CE reside en la aptitud para desarrollar en él vida privada y en su destino específico a tal desarrollo, aunque sea eventual. Vid. con mayor detenimiento Navas SANCHEZ, M.: « ¿Inviolabilidad o intimidad domiciliaria? A propósito de la jurisprudencia constitucional sobre el derecho fundamental a la inviolabilidad del domicilio», RDP, n. ${ }^{\circ}$ 81, 2011, pp. 155-198; MATIA Portilla, F. J., El derecho fundamental a la inviolabilidad del domicilio, McGraw-Hill, Madrid, 1997.

28 Arts. 202 y 203 CP que contemplan el allanamiento en domicilios particulares y en domicilios de personas jurídicas, públicas y privadas.

29 Sentencia del Juzgado de lo Penal n. ${ }^{\circ} 4$ de Alicante 000859/2019, de 30 de diciembre.

30 L.O. 2/2002, de 6 de mayo, reguladora del control judicial previo del Centro Nacional de Inteligencia. Asimismo, en el marco del Derecho comparado, la Corte Constitucional Colombiana en caso C-024 de 1994, resalta la falta de habilitación del investigador privado para realizar funciones que están delimitadas por la reserva judicial y la reserva legal para la policía. Vid. SÁNCHEZ DiEZ, I.: «La incidencia de la investigación privada en los derechos fundamentales. Análisis normativo para la regulación de la actividad en Colombia», Revista Electrónica de Estudios Penales y de la Seguridad, n. ${ }^{\circ}$ 4, 2019.

31 Planchadell Gargallo, A.: «Investigaciones proactivas: Agentes encubiertos», Revista de derecho y proceso penal, n. ${ }^{\circ}$ 49, 2018, pp. 233-240. 
delincuencia organizada, reservada, exclusivamente a funcionarios de la Policía Judicial en el marco de dicha investigación criminal, mediante autorización judicial. Cuyo apartado 7 permite que, en el curso de una investigación llevada a cabo mediante agente encubierto, el juez competente pueda autorizar la obtención de imágenes y la grabación de las conversaciones que puedan mantenerse en los encuentros previstos entre el agente y el investigado, aun cuando se desarrollen en el interior de un domicilio. Así pues, dada la consideración de FFCCSS que éste debe tener, así como en atención a los delitos en el marco de los cuales se puede llevar a cabo su actuación - actividades propias de la delincuencia organizada y, por tanto, perseguibles de oficio, se excluye tajantemente la actuación de los investigadores privados, que, tal y como hemos visto, queda circunscrita a los delitos perseguibles a instancia de parte.

La inviolabilidad del domicilio ha sido entendida de un modo amplio por el Tribunal Constitucional, de modo que no sólo es objeto de protección el espacio físico en sí mismo considerado, sino lo que en él hay de emanación de la persona y de esfera privada de ella; frente toda clase de invasiones incluidas las que puedan realizarse sin penetración directa por medio de aparatos mecánicos, electrónicos u otros análogos ${ }^{32}$. Y, en este sentido, la garantía civil del domicilio está prevista en la Ley 1/1982, de Protección civil del Honor, la Intimidad y la Propia Imagen, en la que se consideran intermisiones ilegítimas, de modo que el art. 7 contempla como tal intromisión el emplazamiento en cualquier lugar de aparatos de escucha, de filmación, de dispositivos ópticos o de cualquier otro medio apto para grabar o reproducir la vida íntima de las personas (apt.1); así como la utilización de aparatos de escucha, dispositivos ópticos, o de cualquier otro medio para el conocimiento de la vida íntima de las personas (apt. 2).

Ahora bien, en este ámbito conviene subrayar que un elemento determinante es la denominada «expectativa de privacidad»; por lo que quedan fuera del ámbito de actuación de la investigación privada cualquier actuación que, aún desde un lugar público, pueda constreñir tal expectativa. Me refiero, por ejemplo, a la toma de fotografías en las que se puede apreciar el interior del domicilio aún desde otro espacio como pueda ser una azotea. La protección del domicilio ampara a la persona que pone barreras en su domicilio, ya que está ejerciendo su legítimo poder de exclusión, y, por tanto, reafirmando en su entorno domiciliario, tal expectativa de privacidad, y ello es lo que determina que no puedan obtenerse imágenes que permitan ver lo que sucede dentro del domicilio. Expectativa de privacidad que ha de ser razonable, sin que se requiera, por ejemplo, encapsular la vivienda con un revestimiento opaco. Por lo tanto, alcanza también los espacios que hemos querido reservar exentos del conocimiento de los demás, mediante la cautela de poner barreras específicas que preserven del conocimiento ajeno el desarrollo de la vida familiar dentro del domicilio. Es lo que el Tribunal Supremo denomina «blindaje con

32 Vid. las citadas SSTC 22/1984, de 17 de febrero y 10/2002, de 17 de enero. 
murallas que constituyen la materialización de la protección del derecho fundamental»; cediendo esa muralla solo en virtud del consentimiento del afectado ${ }^{33}$.

\section{El secreto de las comunicaciones}

Este es uno de los derechos que con mayor frecuencia puede afectarse, debiendo distinguir para su análisis certero dos ámbitos: el personal y el relativo a las comunicaciones corporativas y abiertas en el ámbito laboral.

\section{a) Las comunicaciones personales}

El secreto de las comunicaciones está configurado como una garantía formal que cubre no solo el contenido de la comunicación, sino también otros aspectos de la misma, como la identidad subjetiva de los interlocutores. Así lo reconoció desde bien temprano el TEDH (caso Malone c. Reino Unido, de 2 de agosto de 1984); asumiendo dicha tesis el Tribunal Constitucional desde la STC 114/1984, de 29 de noviembre reafirmándose dicho carácter formal y abstracto, y, en consecuencia, predicándose el secreto de lo comunicado, sea cual sea su contenido y pertenezca o no la comunicación misma al ámbito de lo personal, lo íntimo o lo reservado.

Esta naturaleza jurídica formal implica que la comunicación se protege frente a terceros, ajenos a la misma, pertenezca o no el objeto de la misma al ámbito de lo personal, lo íntimo o lo reservado, sea banal o no, sea relevante o no. No son, pues, las comunicaciones privadas las que determinan el núcleo de la garantía, sino la privacidad de la comunicación, independientemente del contenido que tenga. De ello deriva la presunción iuris et de iure de que lo comunicado es «secreto», en un sentido sustancial ${ }^{34}$.

El artículo 18.3 CE garantiza la impenetrabilidad de las comunicaciones por terceros, tanto públicos como privados; es un derecho que posee eficacia erga omnes $^{35}$. En consecuencia:

33 STS 3754/2018, de 23 de octubre. Asimismo, el TC ha aclarado que no deja de ser domicilio constitucionalmente protegido una vivienda por estar circunstancialmente abierta; siendo consustancial a la noción de vida privada y, por tanto, al tipo de uso que define el domicilio, el carácter acotado respecto del exterior del espacio en el que se desarrolla. «El propio carácter instrumental de la protección constitucional del domicilio respecto de la protección de la intimidad personal y familiar exige que, con independencia de la configuración física del espacio, sus signos externos revelen la clara voluntad de su titular de excluir dicho espacio y la actividad en él desarrollada del conocimiento e intromisiones de terceros» STC 10/2002, de 17 de enero.

34 Ridaura Martinez, M. J.: «El legislador ausente del artículo 18.3 de la Constitución (la construcción pretoriana del derecho al secreto de las comunicaciones», $R D P$, n. ${ }^{\circ} 100,2017$, p. 357

35 Aragón Reyes, M.: «Intervenciones Telefónicas y Postales (examen de la Jurisprudencia Constitucional)», Teoría y Realidad Constitucional, n. ${ }^{\circ}$ 25, 2010. Rebollo Delgado. L.: «El secreto de las comunicaciones: problemas actuales», RDP , n. ${ }^{0} 48-49,2000$, pp. 366 y ss; LuCAs Murillo De La Cueva, P.: «Notas sobre el derecho fundamental al secreto de las comunicaciones», Constitución, Estado de las Autonomías y Justicia 
a) La intervención de las comunicaciones sólo procede y tiene validez ajustándose a las exigencias constitucionales de resolución judicial, dictada con plena sujeción a los principios de especialidad, idoneidad, excepcionalidad, necesidad y proporcionalidad ${ }^{36}$. Y acordada sólo en el marco de una serie de delitos 1. Delitos dolosos castigados con pena con límite máximo de, al menos, tres años de prisión; 2. ${ }^{\circ}$ Delitos cometidos en el seno de un grupo u organización criminal; $3 .^{\circ}$ Delitos de terrorismo ${ }^{37}$. De acuerdo con esta configuración, debe concluirse que no cabe la interceptación de las comunicaciones en el marco de la investigación por los detectives privados, porque ellos no realizan investigación criminal, y porque tampoco son agentes de la autoridad, sin que pueda sustraerse dicha función a la correspondiente intervención judicial.

En la medida en que el secreto de las comunicaciones protege a los interlocutores frente a las intromisiones de terceros, el Tribunal Constitucional $^{38}$, en el marco de un procedimiento penal, consideró como prueba ilícita la interceptación de correos electrónicos por detectives ajenos a la comunicación. En efecto, los recurrentes pretendían la validez de unas pruebas que se habían obtenido con infracción del derecho fundamental al secreto de las comunicaciones, pues contrataron los servicios de una agencia de detectives privados, quienes, tras un seguimiento, accedieron a una serie de datos identificativos protegidos por este derecho fundamental. El Tribunal, corroborando la interpretación de la jurisdicción ordinaria, consideró que los recurrentes se habían arrogado funciones que sólo al instructor le corresponden en el marco del proceso penal, lo que, implica una obtención inconstitucional de la prueba pretendida.

b) Ahora bien, conviene delimitar, también, las escuchas ambientales previstas en la LeCrim ${ }^{39}$, de otro tipo de escuchas que pueden practicarse por particulares, y, por tanto, por detectives.

Constitucional (libro homenaje al profesor Gumersindo Trujillo) / coord. por Luis AguiAr De LuQUe, 2005; Diaz Revorio, J.: «El derecho fundamental al secreto de las comunicaciones», Derecho PUCÓDIGO PENAL, Revista de la Facultad de Derecho, n. ${ }^{\circ}$ 59, 2006, pp. 159-175. RoDríguEZ RuIZ, B: El secreto de las comunicaciones: tecnología e intimidad, McGraw-Hill, 1998. MAtia Portilla, J. «Comentario al Artículo 18.2», Comentarios a la Constitución en homenaje a L. López Guerra (dirs.) Perez Tremps, P. y Saiz Arnaiz, A. (coord.) Montesinos Padilla, C., Tirant lo Blanch, Valencia, 2018, pp. 419-429.

36 Art. 588 bis LECrim.

37 Art. 579 LeCrim, tras la modificación operada por Ley Orgánica 13/2015, de 5 de octubre.

38 ATC 444/2006, de 11 de diciembre, que inadmitió a trámite una demanda de amparo que se sustentaba en la consideración de que dichas pruebas debían tener valor probatorio, alegando que las personas que habían obtenido los datos eran mandatarios de los destinatarios de los mensajes, y, por tanto, aducían que entre los interlocutores de la comunicación no puede haber vulneración del secreto a las comunicaciones. No obstante, tal conclusión es rechazada por las resoluciones cuestionadas, pues los demandantes no eran los únicos destinatarios.

39 Recuérdese el caso de la captación ilegal de la conversación entre la presidenta del PP catalán A. Sánchez-Camacho y la expareja de J. Pujol Ferrusola (hijo mayor del expresidente de Cataluña), V. Álvarez. Grabaciones que se atribuyeron a la Agencia de Detectives Método 3. 
La LeCrim admite la colocación y la utilización de dispositivos electrónicos que permitan la captación y grabación de las comunicaciones orales directas que se mantengan por el investigado, en la vía pública o en otro espacio abierto, en su domicilio o en cualesquiera otros lugares cerrados. Asimismo, contempla la utilización de dispositivos técnicos de seguimiento y localización. Ahora bien, son medidas sujetas a unas exigencias: la autorización por parte del juez de instrucción y que se respeten los principios rectores de especialidad, excepcionalidad, idoneidad, necesidad y proporcionalidad; cuando pueda racionalmente preverse que la utilización de los dispositivos aportará datos esenciales y de relevancia probatoria para el esclarecimiento de los hechos y la identificación de su autor. Precisamente porque estamos ante un supuesto en el que la ley permite dichas intervenciones al «investigado» en el marco de unos delitos determinados ${ }^{40}$.

Se suelen aceptar grabaciones escuchadas en un restaurante al ser considerado un lugar público, pero no la instalación de micros en reservados de restaurantes, que no tienen la consideración de espacios públicos. Aunque es cuestionable que dicha grabación pueda afectar al secreto de la comunicación, ya que incide en la esfera del derecho a la intimidad (art. 18.1 CE), al que nos referiremos más tarde.

c) El único supuesto en que el investigador privado puede grabar la conversación es en el que él es uno de los interlocutores. En efecto, puede grabar y difundir la comunicación siempre y cuando no tenga carácter íntimo, ya que el Tribunal Constitucional ha venido manteniendo constantemente que «No hay «secreto» para aquél a quien la comunicación se dirige, ni implica contravención de lo dispuesto en el art. 18.3 CE» (STC 114/1984). Y, siguiendo esta línea, el Tribunal Supremo reconoce la licitud de las conversaciones privadas grabadas por uno de los interlocutores, pues la vulneración del derecho recogido en el art. 18.3 CE sólo ocurre cuando se graba una conversación «de otro», pero no cuando se graba una conversación «con otro» (STS de 5-04-17).

Hemos podido comprobar cómo el derecho al secreto de las comunicaciones, que protege todo tipo de comunicación — sea privada o no-, no opera entre los interlocutores; ahora bien, la revelación del contenido de la comunicación por parte de uno de ellos ha de reconducirse a la vulneración del derecho

40 De acuerdo con el art. 588 quater b. la utilización de los estos dispositivos ha de estar vinculada a comunicaciones que puedan tener lugar en uno o varios encuentros concretos del investigado con otras personas y sobre cuya previsibilidad haya indicios puestos de manifiesto por la investigación. Y el art. 588 quater c. regula el contenido de la resolución judicial que autorice la medida, que deberá contener, además de las exigencias reguladas en el art. 588 bis c, una mención concreta al lugar o dependencias, así como a los encuentros del investigado que van a ser sometidos a vigilancia. 
a la intimidad (art. 18.1), que no es absoluta, pues no admite el pleno deber de reserva $^{41}$. Es verdad que la grabación subrepticia sin conocimiento del otro interlocutor es considerada mayoritariamente como penalmente atípica. Comparto en este tema el cuestionamiento que expresa González Cussac ${ }^{42}$ al respecto. Consentir el mantenimiento de una comunicación no equivale a consentir su grabación encubierta; lo contrario implicaría constreñir la libertad más allá de lo razonable, por lo que la admisión de dichas grabaciones debería estar sujeta a un juicio de necesidad, idoneidad y proporcionalidad.

\section{b) Comunicaciones en el ámbito laboral}

La investigación privada encuentra un nicho importante en el marco de las relaciones laborales; en el que la contratación de detectives viene siendo muy habitual, no con carácter preventivo, sino para «confirmar las sospechas» de actuación ilegal; proliferando los medios que aseguran dicho control ${ }^{43}$. Y, aun tratándose de comunicaciones, éstas pueden ser objeto de intervención, incluso fuera del marco de un procedimiento judicial, y sin necesidad de autorización judicial. El basamento legal para tales actuaciones se encuentra, por un lado, en la facultad del empleador de auto organización, dirección y control. Y, por otro, en la prohibición convencional del uso extra laboral del correo electrónico, conduciendo al Tribunal Constitucional a admitir la intervención de dichas comunicaciones «siempre con pleno respeto a los derechos fundamentales» ${ }^{44}$.

El poder de control empresarial (art. 20.3 del Estatuto de los Trabajadores) sobre las herramientas informáticas de titularidad empresarial — puestas

41 «Quien entrega a otro la carta recibida o quien emplea durante su conversación telefónica un aparato amplificador de la voz que permite captar aquella conversación a otras personas presentes no está violando el secreto de las comunicaciones, sin perjuicio de que estas mismas conductas, en el caso de que lo así transmitido a otros entrase en la esfera «íntima» del interlocutor, pudiesen constituir atentados al derecho garantizado en el art. 18.1 de la Constitución. Otro tanto cabe decir, en el presente caso, respecto de la grabación por uno de los interlocutores de la conversación telefónica. Este acto no conculca secreto alguno impuesto por el art. 18.3» STC 114/1984, de 29 de noviembre. El TC remarca claramente las diferencias entre los arts. 18.3 y 18.1 en la STC 142/2012, de 2 de julio.

42 Como advierte Gonzalez Cussac, J. Semejante praxis judicial conlleva consecuencias extraordinarias, como, por ejemplo, haber favorecido la ya habitual costumbre de registrar subrepticiamente las conversaciones privadas, con finalidad lícita o ilícita, en prevención de futuros usos, y tanto para iniciar o sostener una acusación como para tratar de armar una defensa «Tutela penal de la intimidad y grabación de la conversación por uno de los interlocutores», Revista Penal, n. ${ }^{\circ}$ 46, 2020, p. 97.

43 Diaz Rodriguez, J.M.: Detectives y vigilantes privados en el ámbito laboral, Tirant lo Blanch, Valencia, 2013 , pp. 61 y ss.

44 STC 241/2012, de 17 de diciembre, precisando que «aun cuando la atribución de espacios individualizados o exclusivos — como la asignación de cuentas personales de correo electrónico a los trabajadorespuede tener relevancia sobre la actuación fiscalizadora de la empresa, ha de tenerse en cuenta que «los grados de intensidad o rigidez con que deben ser valoradas las medidas empresariales de vigilancia y control son variables en función de la propia configuración de las condiciones de disposición y uso de las herramientas informáticas y de las instrucciones que hayan podido ser impartidas por el empresario a tal fin» (FJ 5). 
a disposición de los trabajadores - puede legítimamente ejercerse, tanto a efectos de vigilar el cumplimiento de la prestación laboral realizada a través del uso profesional de estos instrumentos, como para fiscalizar que su utilización no se destinaba a fines personales o ajenos al contenido propio de su prestación de trabajo ${ }^{45}$. De modo que, cuando hay una prohibición expresa para el uso extra laboral del correo electrónico, limitándose sólo a fines profesionales, la facultad de la empresa de controlar su utilización, al objeto de verificar el cumplimiento por el trabajador de sus obligaciones y deberes laborales, está implícita.

Estamos ante comunicaciones que no se realizan a través de medios o canales cerrados; habiéndose validado la intervención de las mismas por detectives privados en el marco de una investigación por incumplimiento laboral. Con mayor claridad la STC 170/2013, de 7 de octubre, corrobora que el art. 18.3 CE protege únicamente ciertas comunicaciones: las que se realizan a través de determinados medios o canales cerrados; por lo que, no gozarán de dicha protección constitucional las comunicaciones abiertas realizadas por un canal del que no puede predicarse la confidencialidad ${ }^{46}$.

De modo que, es posible el acceso, por ejemplo, por la empresa a unos ficheros informáticos en los que quedan registradas las conversaciones electrónicas mantenidas por dos trabajadoras a través de un programa de mensajería, instaladas en un ordenador de uso común a todos los trabajadores, y que no tenía clave de acceso. Y, fundamentalmente, porque la instalación del programa se había producido vulnerando la prohibición de la entidad de instalar programas en el ordenador. Ante esta prohibición y ante la utilización de canales, no privados, sino corporativos no cerrados, no cabe en palabras del Tribunal «una expectativa razonable de confidencialidad derivada de la utilización del programa instalado» (STC 214/2012, de 17 de diciembre).

En todo caso, la actuación de verificación empresarial no puede entenderse de forma excesivamente amplia, sino que ha de estar sujeta a un juicio de proporcionalidad; entendiendo que éste ha de consistir en una justificación de la medida de la intervención, fundándose en la existencia de sospechas de un comportamiento

45 STC 170/2013, de 7 de octubre.

46 El recurrente denunciaba la lesión del derecho a la intimidad y al secreto de las comunicaciones por entender que la empresa se extralimitó en sus facultades de fiscalización, puesto que no le había informado previamente sobre las reglas de uso y control de las herramientas informáticas de la entidad, y, sin embargo, procedió a interceptar de forma ilícita el contenido de sus correos electrónicos registrados en el ordenador facilitado por la empresa. En este caso concurrían unas determinadas circunstancias: las partes del proceso quedaban dentro del ámbito de aplicación del XV Convenio colectivo de la industria química, acordado por la Federación Empresarial de la Industria Química Española y por los sindicatos FITEQA-CCOO y FIA-UGT (resolución de la Dirección General de Trabajo de 9 de agosto de 2007, BOE de 29 de agosto de 2007). En cuyo art. 59.11 tipificaba como falta leve la «utilización de los medios informáticos propiedad de la empresa (correo electrónico, Intranet, Internet, etc.) para fines distintos de los relacionados con el contenido de la prestación laboral, con la salvedad de lo dispuesto en relación con los derechos sindicales. 
irregular del trabajador. Además, esta intervención ha de ser idónea para la finalidad pretendida por la empresa, consistente en verificar si el trabajador cometía efectivamente la irregularidad sospechada; la medida ha de considerarse necesaria, dado que, como instrumento de transmisión de dicha información confidencial, el contenido o texto de los correos electrónicos serviría de prueba de la citada irregularidad ante la eventual impugnación judicial de la sanción empresarial. Finalmente, la medida ha de ser ponderada y equilibrada ${ }^{47}$.

Es la Sentencia del TEDH (Gran Sala) (Caso Barbulescu contra Rumania, de 5 septiembre de 2017), la que concreta las exigencias que permitan el control de las comunicaciones en el ámbito empresarial: de modo que ha de informarse, previamente, al trabajador de que sus comunicaciones puedan ser controladas; para ser considerada como previa, la advertencia del empleador debe darse antes de que comience la actividad de supervisión. Ha de informarse de la naturaleza y alcance de la vigilancia, así como del grado de intrusión en su vida privada y en su correspondencia. Debe determinar los motivos concretos que justifica la introducción de las medidas de control. Y, ha de determinar si el empresario puede optar por utilizar medidas menos intrusivas para la vida privada y la correspondencia del trabajador.

\section{Derecho al honor, a la intimidad, a la propia imagen y a la protección de datos de carácter personal}

Determinadas funciones de los servicios de investigación privada pueden incidir plenamente sobre derechos de la esfera personal, que aseguran la existencia de un ámbito propio y reservado frente a la acción y conocimiento de los demás; nos estamos refiriendo a los derechos contemplados en el art. 18.1 y 4 CE.

\section{a) Derecho al Honor}

En relación con el derecho al honor, entendido como un derecho que ampara la buena reputación de una persona, protegiéndola frente a mensajes o expresiones que puedan hacerla desmerecer en su consideración ajena ${ }^{48}$, no sería inverosímil que en el marco de una investigación privada se obtuvieran y difundieran datos que pudieran dañar el honor, tanto de personas físicas como de personas jurídicas; pues también a estas últimas se les ha venido reconociendo por la doctrina constitucional la titularidad del derecho en cuestión. En efecto, el propio

47 Dichos correos sólo contenían información relativa a la actividad empresarial, cuya remisión a terceros implicaba una transgresión de la buena fe contractual. «De ahí que, atendida la naturaleza de la infracción investigada y su relevancia para la entidad, no pueda apreciarse que la acción empresarial de fiscalización haya resultado desmedida respecto a la afectación sufrida por la privacidad del trabajador».

48 SSTC 105/1990, de 6 de junio y 49/2001, de 26 de febrero, entre otras. 
Tribunal Constitucional reconoce que se puede incluir dentro del derecho al honor el prestigio profesional o comercial, tanto respecto de personas físicas como jurídicas ${ }^{49}$, por lo que la información que pudiera divulgarse sobre las mismas podría suponer una transgresión de su honor. De hecho, se han llegado a plantear demandas por vulneración del honor tras la difusión de grabaciones obtenidas ilícitamente por detectives.

\section{b) Derecho a la Intimidad ${ }^{0}$}

El derecho a la intimidad garantiza al individuo la existencia de un ámbito propio y reservado frente a la acción y el conocimiento de los demás, referido preferentemente a la esfera estrictamente personal de la vida o de lo íntimo, e imponiendo a los terceros el deber de abstenerse de toda intromisión en esa esfera y la prohibición de hacer uso de lo conocido, salvo justificación legal o consentimiento del afectado ${ }^{51}$.

Diversas actuaciones de la investigación privada pueden incidir sobre dicha esfera de la intimidad, que tiene un contenido muy amplio.

\section{Utilización de Cámaras}

La Ley 5/2014 de Seguridad Privada incluye la utilización de los servicios de video vigilancia, permitiendo la instalación de sistemas de cámaras o videocámaras, fijas o móviles, capaces de captar y grabar tanto imágenes como sonidos, incluido cualquier medio técnico o sistema que permita los mismos tratamientos que éstas. Ahora bien, esta previsión no se extiende a todos los integrantes a los que se refiere la Ley; sino que viene referida a las funciones de Seguridad y, en consecuencia, no a las de investigación ${ }^{52}$.

La intimidad frecuentemente suele verse afectada por el uso de cámaras que en muchas ocasiones suelen ser ocultas ${ }^{53}$, respecto de las cuales sólo en los

49 STC 40/1992, de 30 de marzo, en la que reconoce la reiterada jurisprudencia del propio TS que incluye el «honor profesional» dentro del ámbito de protección de la L.O. 1/1982, de 5 de mayo, de manera que cualquier intromisión ilegítima en dicho derecho personalísimo, independientemente de la actividad profesional de la persona en que recaiga la intromisión ilegítima, ha de ser protegido.

50 Carrillo, M.: «Comentario al Artículo 18.1», Comentarios a la Constitución en homenaje a L. López Guerra (dirs.) Perez Tremps, P. y Saiz Arnaiz, A. (coord.) Montesinos Padilla, C., Tirant lo Blanch, Valencia, 2018, pp. 405-418.

51 Garcia Roca, F.J.: «El derecho a la intimidad», RCG, n. ${ }^{\circ} 37,1996$, pp. 473-483.

52 El borrador del Reglamento en su art. 187. 3. establece que la utilización de cámaras de videograbación en los servicios de investigación privada por parte de los detectives privados no tendrá la consideración de servicio de videovigilancia.

53 Villaverde Menendez, I.: «A propósito de la reciente jurisprudencia del Tribunal Constitucional sobre el empleo de «cámaras ocultas», Derecom, n. ${ }^{\circ}$ 10, 2012. 
supuestos en donde no se emplean métodos constitucionalmente vedados y el acceso es casual o de buena fe, no siempre podrá afirmarse que lesionan ilegítimamente el derecho a la intimidad personal; de modo que «la ausencia de conocimiento y, por tanto, de consentimiento de la persona reproducida respecto a la intromisión en su vida privada es un factor decisivo en la necesaria ponderación de los derechos en conflicto» ${ }^{54}$.

$Y$, nuevamente en el marco laboral encontramos un terreno abonado para las grabaciones, refiriéndonos sólo a las empleadas por detectives privados. Las facultades de control del empresario permiten la instalación de dispositivos de grabación que permitan obtener pruebas sobre los eventuales incumplimientos derivados del puesto de trabajo; de ahí que viene siendo habitual la contratación de un investigador privado para la obtención de pruebas que corroboren dicho incumplimiento contractual. Ello nos conduce a la prestación de un servicio al cliente en virtud de disposición legal; estando contemplado en la propia Ley de Seguridad privada, y, en todo caso, siempre que exista un interés legítimo previsto en la normativa sobre protección de datos.

Se plantean en qué medida cabe la contratación por la empresa de servicios de detectives privados para fiscalizar la actuación fuera de la empresa así como del horario laboral. Está claro que las facultades de control sólo pueden extenderse a la investigación de la vida del trabajador de las que pueda derivarse ilicitudes contra el empresario; pues no cabría la realización de averiguaciones de la vida personal que no tengan ninguna conexión, no tanto con los intereses empresariales, sino más concretamente con el cumplimiento de su trabajo.

El Tribunal Supremo ha vuelto a confirmar la licitud y validez probatoria de las grabaciones realizadas con sistemas ocultos en empresas durante servicios de investigación privada ${ }^{55}$.

54 Doctrina sobre la protección de la vida privada frente al uso de dispositivos de captación de imagen y voz ocultos o clandestinos (Sentencia del Tribunal Supremo 12/2012 de 12 de diciembre de 2012; SSTEDH caso Jersild c. Dinamarca, de 23 de septiembre de 1994; caso MGN Limited c. Reino Unido, de 18 de enero de 2011 y caso Mosley c. Reino Unido, de 10 de mayo de 2011.

55 ATS 14185/2018, de 13 de diciembre (Sala de lo Social), confirmando la sentencia en la que se partía sin embargo de la sustracción de un ordenador portátil en la empresa en una sala de acceso restringido y de la contratación de los servicios de un detective privado que instaló una cámara oculta en dicha sala, considerando la sala entonces que la medida superaba los juicios de idoneidad y necesidad, por entender además que el acceso restringido de trabajadores a dichas dependencias se limitaba a los trabajadores y a los tiempos de acceso a dicha sala, y que ese era el ámbito restringido de protección de los derechos fundamentales, por lo que la medida cumplía los requisitos fundamentales de eficiencia de la medida. Por su parte, en la STEDH de 17 de octubre de 2019 (caso López Ribalda y otros c. España — Gran sala-) el Tribunal declaró que no se había producido vulneración del arículo 6.1 del CEDH ya que, por un lado, a las demandantes se les había permitido cuestionar la autenticidad de las grabaciones en el proceso judicial, y por otro, las decisiones judiciales no se basaron únicamente en esas grabaciones sino también en declaraciones testificales. Tampoco entendió que los acuerdos o finiquitos se suscribieran bajo amenazas o coacciones del empleador. Sin embargo, aun tratándose del uso de cámaras en el lugar del trabajo, al no referirse a actividad del detective privado no procederemos a su análisis. 
En todo caso, existe una consolidada doctrina constitucional ${ }^{56}$ acerca de las exigencias que ha de cumplir la instalación de una cámara para verificar incumplimientos contractuales, que se concreta en la determinación del juicio de proporcionalidad; para ello es necesario constatar si cumple los siguientes requisitos: si tal medida es susceptible de conseguir el objetivo propuesto (juicio de idoneidad); si, además, es necesaria, en el sentido de que no exista otra medida más moderada para la consecución de tal propósito con igual eficacia (juicio de necesidad); y, finalmente, si la misma es ponderada o equilibrada, por derivarse de ella más beneficios o ventajas para el interés general. Por tanto, sólo es constitucionalmente admisible en la medida en que sea absolutamente indispensable para proteger la seguridad de la empresa. Si no se supera este escrupuloso test de indispensabilidad se considera una intromisión ilegítima en el derecho a la intimidad de los trabajadores; no aceptándose el control oculto más que cuando sea estrictamente necesario para detectar las actividades fraudulentas o ilícitas del trabajador ${ }^{57}$.

Utilización de dispositivos de geolocalización (GPS) y drones

Las nuevas tecnologías inciden plenamente sobre el derecho a la intimidad, encontrándonos con instrumentos que permiten el seguimiento y la localización de las personas, como son los GPS, datos biométricos o el uso de drones.

En el caso de la geolocalización, en tanto en cuanto que afecta al derecho del trabajador y supone un tratamiento de datos, éste ha de estar informado ${ }^{58}$

En el ámbito laboral, el Tribunal Supremo ha considerado lícitos los datos del geolocalizador en un vehículo de empresa si el trabajador está informado de su instalación, declarando procedente el despido disciplinario de una empleada por uso del coche de empresa fuera de la actividad laboral, a pesar de que lo tenía restringido ${ }^{59}$. Y en diversas ocasiones, la jurisdicción ordinaria ha venido aceptando el uso de estos dispositivos por los detectives en el ejercicio de su oficio; así la Audiencia Provincial de Cantabria ${ }^{60}$ ha dictado Sentencia absolviendo de un

56 SSTC 29/2013, de 11 de febrero; 186/2000, de 24 de julio; 98/2000, de 10 de abril y 186/2000, de 10 de julio, entre otras.

57 GoÑ SeIn, J.L: La videovigilancia empresarial y la protección de datos personales, Thomson Civitas, Madrid, 2007, pp. 128-129. Quien entiende que adoptar un sistema de videovigilancia en el lugar de trabajo sin conocimiento del trabajador no sólo constituye una legítima privación del derecho a disponer de los propios datos personales, sino una intromisión ilegítima en el ámbito protegido por el derecho a la esfera privada del trabajador. Por lo que, no se puede descartar por completo la posibilidad de control oculto, pues en ocasiones, el recurso a la videovigilancia solo es eficaz si se adopta de forma secreta.

58 Esteve Segarra, A.: «El control de la actividad representativa: especial referencia al crédito horario de los representantes de los trabajadores, TAlens, Visconti, E. y VAlls Genovard, M. A. (drs.): La actividad de los detectives privados en el ámbito laboral, Bosch, Wolters Kluwer, Madrid, 2020, p. 78, así como AleGRE Nueno, M.: «La utilización de sistema de geolocalización para controlar la actividad laboral», pp. 175-194.

59 STS 3017/2020, de15 de septiembre de 2020.

60 SAP de Cantabria, de 7 de marzo de 2018. 
delito leve de coacciones a un detective privado que, en el ejercicio de su oficio, había colocado dos dispositivos GPS en el vehículo de un particular al que venía haciendo un seguimiento: la colocación en el vehículo de un GPS no es un acto violento, como tampoco lo es establecer una vigilancia sobre las acciones de una persona en la vía pública y, además, no se restringe la libertad deambulatoria del sujeto investigado ya que lo que el detective desea es que se mueva libremente, coja el coche y desarrolle su actividad profesional al objeto de informar sobre su horario laboral.

La citada Sentencia de la Audiencia entiende que el empleo de un localizador GPS adherido al automóvil es un medio técnico que facilita, sin sustituir, la labor de seguimiento del investigado cuando se mueve en coche por las vías públicas ya que el GPS únicamente localiza y sitúa geográficamente al vehículo, no a la persona que lo conduce.

En el mismo sentido, la Audiencia Provincial de Jaén, también ha considerado que la utilización de los dispositivos de GPS por parte de los detectives privados en el ejercicio de su oficio resulta admisible en tanto la labor se desarrolle en la vía pública, no restringa la libertad deambulatoria y el dispositivo técnico no sustituya la labor del detective. Razonando que, sobre la base de que el Código Penal castiga a las personas que se apoderen de cartas, papeles, mensajes de correo electrónico o documentos personales de otra persona, o a los que pinchen teléfonos con penas de uno a cuatro años de prisión, considerándose que su finalidad es la de proteger la intimidad de los ciudadanos. Sin embargo, ante la ausencia de mención expresa de un GPS en el coche., la Audiencia de Jaén amparándose en ese 'vacío' en la redacción del artículo 197.1 del Código Penal ha absuelto a un detective privado que instaló una baliza para localizar y rastrear los movimientos de un hombre al que investigaba por encargo de una compañía de seguros ${ }^{61}$.

Con relación a los drones ${ }^{62}$, cada vez de uso más frecuente, hay que ajustarse a las exigencias contempladas, tanto en el marco que Agencia Estatal de Seguridad Aérea (AESA), dependiente del Ministerio de Fomento, cristalizado en el Real Decreto 1036/2017, de 15 de diciembre, así como en la L.O. 3/2018, de 5 de diciembre, de Protección de Datos Personales y garantía de los derechos digitales, ya que en todo caso deben respetar el derecho fundamental a la vida privada y a la protección de datos, que pueden verse seriamente dañados, «pueden almacenar y procesar datos e imágenes de gran cantidad de población, que estaría sometida a una vigilancia continuada sin saberlo y sin ser consciente de ello» ${ }^{63}$.

En síntesis, cabe afirmar, como lo hace certeramente Eloy Velasco ${ }^{64}$, que las exigencias requeridas en relación con las nuevas tecnologías son «igualmente pre-

61 SAP de Jaén de 5 de marzo de 2019.

62 Pauner Chulvi, C.: «El uso emergente de drones civiles en España. Estatuto jurídico e impacto en el derecho a la protección de datos», $R D P$, n. $^{\circ} 95,2016$, pp. 83-116.

63 González Puente, C. y González Botija, F.: «Los drones y los derechos fundamentales en la UE», Revista Universitaria Europea n. ${ }^{\circ}$ 29, 2018, pp. 77-114.

64 Velasco NúÑEZ, E.: «Investigación procesal penal de redes, terminales, dispositivos informáticos, imágenes, GPS, balizas, etc.: la prueba tecnológica» Diario La Ley, n. ${ }^{\circ} 8183,4$ de noviembre de 2013 , 
dicable de las investigaciones particulares hechas frente a terceros por detectives privados o personas no pertenecientes a los cuerpos policiales, cuando usan tecnologías de vigilancia privadas.

$Y$, en consecuencia, se requiere que se ponderen factores tales como la existencia de un fin constitucionalmente legitimo; que la intervención desarrollada cuente con habilitación legal, y que sea necesaria y proporcional.

\section{c) El derecho a la propia imagen}

El derecho a la propia imagen tiene dos vertientes: el derecho a ser uno mismo; y el derecho a que no se haga uso de la imagen de uno mismo sin su consentimiento, permitiendo a su titular que impedir que se capte, reproduzca o publique. Por ello, siendo la primera de ella exclusivamente personal, aunque admite ciertas limitaciones, por ejemplo, por razones laborales ${ }^{65}$, no afecta a la investigación privada, que se centra, exclusivamente, en la segunda vertiente.

Este suele ser un ámbito en el que los detectives son contratados por compañías aseguradoras en orden a la averiguación de actuaciones fraudulentas, destacando, por su especial relieve la Sentencia del Tribunal Europeo de Derechos Humanos de 27 de mayo de 2014 (asunto de la Flor Cabrera contra España) ${ }^{66}$. En dicha Sentencia el Tribunal Europeo entiende que la grabación video gráfica de una persona en una vía pública, realizada por una agencia de detectives, en el ejercicio legítimo de su actividad, y aportada como prueba en el proceso instado, no constituye una injerencia ilegítima en sus derechos a la intimidad, honor o a la propia imagen, según el artículo 8 del Convenio Europeo de Derechos Humanos ${ }^{67}$.

Editorial LA LEY «—de modo que aplicaciones como la «sígueme» de Apple, que permite desde un terminal móvil por técnicas GPS saber en todo momento y sobre mapa dónde está un tercero (hija desobediente, esposo infiel o padre con alzhéimer) precisan del consentimiento del afectado o mandamiento judicial—».

65 López Balaguer, M. y Talens Visconti, E.: «El seguimiento de las bajas por IT y por IP en el ámbito privado en la doctrina de los tribunales», TAlens, Visconti, E. y Valls Genovard, M. A. (dirs.): La actividad de los detectives privados en el ámbito laboral, cit., 2020. En dicho capítulo se realiza un análisis pormenorizado de la jurisprudencia ordinaria.

66 Pascual Medrano, A: «Due process» y derecho fundamental de la propia imagen: A propósito de la STEDH de 27 de mayo de 2014 (De la Flor Cabrera c. España)», Revista Aranzadi Doctrinal, n. ${ }^{\circ}$ 6, 2014 , pp. 129-138.

67 El demandante, que había sido atropellado por un vehículo mientras realizaba un paseo en bicicleta, presentó una demanda contra el conductor del vehículo y la compañía de seguros implicada, por daños y perjuicios alegando su incapacidad, a raíz del accidente, para conducir vehículos a motor (alegaba neurosis post traumática que le acarreaba, según él, un miedo intenso para conducir vehículos). En el proceso, la compañía aseguradora presentó un video grabado en lugares públicos por una agencia de detectives privados en el cual se veía al demandante conducir una moto. En el recurso ante la Audiencia Provincial, ésta se pronunció en favor del informe de la agencia de detectives, estimando que las circunstancias en las que habían sido tomadas estas imágenes no constituían ni una interferencia en el comportamiento ni un condicionamiento del demandante. Paralelamente, el demandante promovió un procedimiento contra la compañía aseguradora por vulneración de su derecho a la vida privada y a su imagen. 
Las imágenes contradecían las afirmaciones del demandante según las cuales había quedado incapacitado, a raíz de su accidente, para conducir vehículos a motor. En la medida en que su solicitud de indemnización estaba fundada en esta incapacidad, el TEDH juzga razonable considerar que éstas tenían la intención de contribuir de manera legítima al debate judicial, con el fin de permitir al asegurador poner a disposición del Juez todo elemento que probara lo contrario. Las conclusiones que pueden extraerse son las siguientes:

a) las imágenes se tomaron mientras el demandante se encontraba realizando una actividad susceptible de ser grabada; esto es, mientras conducía una moto para desplazarse por la vía pública.

b) las imágenes fueron grabadas por una agencia de detectives privados que respetaba el conjunto de exigencias legales establecidas por la legislación nacional para realizar este tipo de actividades: estaba debidamente autorizada por el Estado e inscrita en el registro administrativo correspondiente, y la toma de imágenes para su utilización en el marco de un proceso está prevista por el artículo 265 de la Ley de Enjuiciamiento Civil.

c) Tales imágenes se utilizaron exclusivamente como medio de prueba ante un juez; sin que existiera un riesgo de utilización posterior.

Incluso imágenes publicadas en redes sociales —en este caso particular Facebook- han servido como prueba para demostrar la transgresión de la buena fe contractual del artículo 54.2.d) del Estatuto de los Trabajadores; confiriéndose valor probatorio a la difusión en la red —accesible a múltiples personas. Si bien, las imágenes que se obtienen a través de redes sociales han de obtenerse siempre y cuando sean públicas o se puede tener acceso legítimo a la mismas. Ya que quien las deja en abierto está implícitamente renunciando a su reserva. «no se precisa de autorización judicial para conseguir lo que es público y el propio usuario de la Red es quien lo ha introducido en la misma ${ }^{68}$. Aunque pueda sorprender, suele ser bastante frecuente subir imágenes en abierto que demuestran que la persona no está de baja justificada, sino de viaje de placer. Y, la utilización de dichas redes sociales no lo es sólo a efectos de comprobación de infracciones, sino también para obtener información sobre candidatos en las contrataciones, planteándose, como advierten Nores y Goerlich su alcance; esto, es, hasta qué punto éstos se han de ceñir a sólo informaciones profesionales o pueden también referirse a aspectos de la vida privada ${ }^{69}$.

68 STS, 236/2008, de 9 de mayo.

69 Nores Torres, L. E. y Goerlich Peset, J.M.: «Protección de la privacidad digital: derecho a la desconexión e investigación en redes sociales», Talens, Visconti, E. y VAlls Genovard, M. A. (drs.): La actividad de los detectives privados en el ámbito laboral, cit., pp. 126 y 127. 
Ahora bien, en el ámbito privado, siendo que es en el que en espacios públicos se suele recurrir a la captación de imágenes, ha de tenerse en cuenta que la captación o reproducción de imágenes por un investigador privado está sujeta a las exigencias de su contenido esencial, determinado por su ámbito de protección que comprende la facultad de poder impedir la obtención, reproducción o publicación de la propia imagen por parte de un tercero no autorizado, sea cual sea la finalidad perseguida por quien la capta o difunde, y, por lo tanto, abarca - la defensa frente a los usos no consentidos de la representación pública de la persona que no encuentren amparo en ningún otro derecho fundamental ${ }^{70}$.

\section{d) Protección de datos de carácter personal}

El alcance del derecho comprendido en el artículo 18.4 CE ha sido expuesto por Lucas Murillo ${ }^{71}$ quien lo ha entendido como «el control que a cada uno de nosotros nos corresponde sobre la información que nos concierne personalmente, sea íntima o no, para preservar de este modo y en último extremo la propia identidad, nuestra dignidad y libertad.». La protección de datos (artículo 18.4) es un derecho que excede el ámbito propio del derecho a la intimidad (artículo 18.1) y que se traduce en un derecho de control sobre los datos relativos a la propia persona. La llamada libertad informática es así el derecho a controlar el uso de los datos insertos en un programa informático (habeas data) y comprende, entre otros, la oposición del ciudadano a que determinados datos personales sean utilizados para fines distintos de aquel que justificó su obtención (STC 292/2000, de 30 de noviembre).

En la medida en que nos encontremos ante un dato, objeto de tratamiento, debemos plantearnos cuales son los supuestos en los que la propia Ley Orgánica permite su acceso a los terceros; ya que ello nos permitirá resolver, con carácter general, el conflicto entre el derecho a la protección de datos y su utilización en el marco de la investigación privada. Es la propia Ley Orgánica de Protección de Datos Personales y garantía de los derechos digitales la que nos da las pautas para clarificar cuando es posible el acceso a los datos por parte de un tercero (en el caso que nos ocupa investigador privado); ya que la comunicación a terceros de los datos requiere el consentimiento del interesado, excepto en los casos previstos expresamente en la Ley. En definitiva, nos hallamos ante un poder de disposición sobre los datos personales, el denominado Habeas Data. La Agencia Española de

70 STEDH caso Von Hannover c. Alemania, de 24 de junio de 2004; así como la STC 23/2010, de 27 de abril, FJ 4, entre otras.

71 Lucas Murillo De La Cueva, P: (1993) Informática y protección de datos personales (estudios sobre la Ley Orgánica 5/1992 de Regulación del Tratamiento Automatizado de los Datos de Carácter Personal. CEC, Madrid, 1993 , p. 51. 
Protección de Datos ${ }^{72}$ considera lícito el tratamiento de datos de carácter personal que puedan derivarse de la realización de actividades de investigación privada, siempre que resulte ajustado a los principios de limitación de la finalidad y minimización y que quede circunscrito al ámbito del encargo en cuyo seno se desarrolla la actividad investigadora, respetando los citados principios y siendo regulada esta actividad mediante la existencia de una relación contractual.

$\mathrm{Y}$, en este marco, nos podemos plantear varios supuestos, a título de ejemplo, que nos pueden indicar cuando es posible la obtención de información por el investigador privado:

Una grabación de la voz de una persona en el marco de una conversación no cubierta por el secreto de las comunicaciones sólo podrá ser consideradas como dato de carácter personal cuando permita la identificación de las personas que aparecen en dichas voces, no encontrándose amparadas en la Ley Orgánica en caso contrario; conduciéndonos, por tanto, a la posible vulneración del derecho a la intimidad.

Podríamos plantearnos si puede acceder a un fichero automatizado sólo en el caso de que dicho fichero pertenezca a la empresa que le ha contratado y firma un contrato con ella. Ahora bien, en el caso de que el fichero sea público, puede tener el mismo acceso que cualquiera otra persona; alegando un interés legítimo: por ejemplo, un Registro de la propiedad o de matrículas de vehículos pueden permitir aducir dicho interés legítimo, si la investigación va dirigida a obtener datos sobre un moroso que está alzando bienes.

En alguna ocasión se plantea la obtención de informaciones relativas a creencias religiosas o ideas políticas; que sólo podrían obtenerse si el titular del derecho las hace pública, pero en caso contrario no permitirían su indexación o utilización para crear un perfil laboral ${ }^{73}$.

En síntesis, toda actuación del investigador privado en este marco deberá respetar los principios de proporcionalidad, idoneidad e intervención mínima.

Debe destacarse, por su interés, la Sentencia del TJUE IPI $(\mathrm{C}-473 / 12)^{74}$, en la que se aborda el tema de la obtención de información por parte de los detecti-

72 Guía sobre el uso de videocámaras para seguridad y otras finalidades, AEPD, Madrid, p. 34.

73 Adviértase que Real Decreto Legislativo 5/2000, de 4 de agosto, por el que se aprueba el texto refundido de la Ley sobre Infracciones y Sanciones en el Orden Social, al regular las Infracciones de los empresarios, de las agencias de colocación, entre otras contempla en su art. 16.1.c que constituye una infracción muy grave $\ll$ c) Solicitar datos de carácter personal en los procesos de selección o establecer condiciones, mediante la publicidad, difusión o por cualquier otro medio, que constituyan discriminaciones para el acceso al empleo por motivos de sexo, origen, incluido el racial o étnico, edad, estado civil, discapacidad, religión o convicciones, opinión política, orientación sexual, afiliación sindical, condición social y lengua dentro del Estado».

74 Un organismo profesional (IPI), con la finalidad de investigar infracciones de la deontología de una profesi6n regulada, contrata los servicios de un detective privado para que este último investigue si determinadas personas que se hacen pasar por agentes inmobiliarios realmente lo son. Se pone en cuestión si la obtención de dicha informacion que contiene determinados datos personales por parte de estos detectives privados ha vulnerado el contenido de la Directiva 95/46. Vid. Palma OrTigosA, A: «STJUE IPI, C-473/12», European Journal of Privacy Law \& Technologies, Section II: Comments on decisions, Vol 1, 2019, pp. 75-77. 
ves privados — sin comunicación al interesado - en el marco de una investigación sobre intrusismo profesional, con infracciones de las normas de deontología. Planteándose si dicha información puede obtenerse, ya que los datos recabados constituyen datos personales, al corresponderse con personas físicas identificadas o identificables; o bien puede entenderse como una de las excepciones permitidas a los Estados para recabar ciertos datos, aún sin el conocimiento del interesado. Y concluyendo que la actividad de detective privado que actúa para un organismo profesional a fin de investigar infracciones de la deontología de una profesión regulada —en el presente caso, la de agente inmobiliario estaba regulada en la vigente entonces Directiva 95/46. Pero, siempre y cuando un Estado miembro hubiera decidido trasponer esta excepción relativa a un organismo profesional y los detectives privados que actúan para él pueden invocarla; no quedando sujetos a la obligación de informar al interesado. En caso contrario, los interesados debían ser informados del tratamiento de sus datos personales.

Sin embargo, debe hacerse notar que dicha previsión no aparece contemplada en la Directiva 2016/680. Planteándose, así, la duda acerca de la continuidad en la línea interpretativa llevada a cabo por el propio Tribunal. Pero, la Agencia de Protección de Datos española ha determinado que «los tratamientos de datos personales que lleven a cabo las empresas de seguridad, despachos de detectives privados y personal de seguridad privada, incluida la comunicación de datos a las Fuerzas y Cuerpos de Seguridad en cumplimiento de la obligación legal establecida en el artículo 14.2 de la Ley de Seguridad Privada, no están incluidos en el ámbito de aplicación de la Directiva 2016/680, quedando sujetos a lo dispuesto en el RGPD» ${ }^{75}$.

\section{EL VALOR PROBATORIO DE LAS PRUEBAS OBTENIDAS POR INVESTIGADORES PRIVADOS}

Las pruebas obtenidas por un investigador privado pueden tener un alcance meramente interno, para quien contrata la investigación alegando un interés legítimo. Esto es, no siempre dicha información ha de acabar como prueba en un proceso. Pero también tiene una relevancia procesal, ya que, como advierte Ángel Blasco, «normalmente, sus averiguaciones se plasman en un informe escrito (acompañado, en ocasiones, de imágenes en fotografías o vídeos) que el cliente utiliza para acreditar su contenido fáctico ante los órganos judiciales»; de modo que dichas pruebas, «una vez introducidas en el juicio, pueden servir para formar la convicción judicial» ${ }^{76}$.

75 N/REF: 010308/2019.

76 Blasco Pellicer, A.: Prologó al libro Talens, Visconti, E. y Valls Genovard, M. A. (dirs.): La actividad de los detectives privados en el ámbito laboral, cit., pp. 7 y ss. 
El detective puede actuar en un proceso a través de dos vías:

a) Como testigo, ya que su informe tiene la calificación de testifical, en virtud del artículo 265.1. 5 de la Ley de Enjuiciamiento Civil que establece, de entre los documentos que pueden acompañar a la demanda, «Los informes, elaborados por profesionales de la investigación privada legalmente habilitados, sobre hechos relevantes en que aquéllas apoyen sus pretensiones. Sobre estos hechos, si no fueren reconocidos como ciertos, se practicará prueba testifical». Y, así, el Tribunal Supremo ha venido sosteniendo reiteradamente que la naturaleza jurídica de los informes de detectives, aunque se presenten por escrito, corresponde propiamente a una prueba testifical, que carece de utilidad para la modificación de los hechos probados en suplicación ${ }^{77}$.

b) $\mathrm{O}$ bien como perito, en el caso en que su intervención responda, de acuerdo con el artículo 370.4 de la misma ley, a sus conocimientos científicos, técnicos, artísticos o prácticos sobre la materia a que se refieran los hechos del interrogatorio.

Ahora bien, dicho carácter probatorio del Informe estará en función de que se haya obtenido respetando los derechos fundamentales. Hemos podido comprobar a lo largo de este estudio diversos casos en los que no se ha reconocido valor probatorio al informe emitido por detectives al no respetar los derechos fundamentales. Sirva ahora de ejemplo la Sentencia del Tribunal Supremo 908/2016, de 30 de noviembre, de 2018, en la que la Sala no reconoció valor probatorio al informe emito por unos detectives contratados por un concejal del municipio del que era vecino el acusado. Dicho informe resumía la vigilancia a la que había sido sometido el acusado para comprobar el cumplimiento de la pena de trabajos en beneficio de la comunidad que se le había impuesto. Pero, la información relativa al cumplimiento de la pena la obtuvo el concejal prescindiendo de los cauces legales, ya que recibió una copia del plan de ejecución de la pena por error, y trasladó los datos personales obtenidos, incluso especialmente protegidos, a los detectives. En consecuencia, la vigilancia y las pruebas estaban viciadas en su origen, ya que se había producido una cesión injustificada e inconsentida de datos protegidos, vulnerando, en consecuencia, el artículo 18.4 de la Constitución. Además, se habían rebasado los límites previstos en la LSP, ya que se trataba de un delito perseguible de oficio (quebrantamiento de condena).

Particular interés tiene la más reciente Sentencia del Tribunal Supremo $155 / 2020$, de 19 de febrero que considera prueba ilícita, sin valor jurídico alguno, el informe de una detective privada contratada por una empresa que forzó una entrevista profesional simulada con un trabajador para demostrar que durante su

77 Por todas, STS 236/2008, de 9 de mayo. 
jornada laboral trabajaba por cuenta propia como abogado, al haber vulnerado el derecho a la dignidad del trabajador. Ratificándose el valor del informe del detective como testifical; así como la doctrina de la «fruta del árbol envenenado».

En síntesis, por un lado, en el marco del proceso, carecen de valor probatorio los informes de detective cuyas pruebas se han obtenido vulnerando derechos fundamentales, quedando proscrito, pues, que el órgano judicial pueda fundar su decisión en pruebas obtenidas, directa o indirectamente, violentando derechos fundamentales o libertades públicas. La posición de la jurisdicción ordinaria ha sido firme en este sentido, elevando «a principios constitucionales los de respeto a la dignidad de la persona y a su absolutamente libre y espontánea determinación, proscribiendo toda acción coactiva sobre la voluntad ajena, así como la utilización de procedimientos ilícitos o éticamente reprobables», así se ha venido reconociendo en diversos pronunciamientos.

Por otro lado, y al margen del valor probatorio de las pruebas obtenidas por los investigadores privados, toda su actuación, acabe o no como prueba en un proceso, ha de sujetarse a las exigencias derivadas del texto constitucional y de las demás normas integrantes del ordenamiento, pues no pueden quedar zonas ajenas al respeto de los derechos, ni para los poderes públicos, ni para los privados.

$$
* * *
$$

TITLE: Fundamental rights as limits in the framework of private investigation

ABSTRACT: The purpose of this work is the analysis of the information obtained by private investigation agents; that is, private detectives, who are authorized by law to practice this profession. It analyses how such an investigation can be carried out, how it must be obtained, and, ultimately, what scope it can have; that is, what the consequences can be, and what evidential value their reports can have in the framework of a process. All this with the purpose of framing the private investigation in the demands derived from the constitutional text of respect of the fundamental rights, starting from its effectiveness so much vertical, as horizontal; taking into account that the action of the detectives, more and more demanded, affects rights that are nuclear, notably, the protection of the domicile, the secret of the communications, as well as the rights to the honour, to the intimacy, to the own image, and data protection.

RESUMEN: Este trabajo tiene como objeto el análisis de la obtención de información por parte de los agentes privados de investigación; esto es los detectives privados, habilitados por la ley para el ejercicio de dicha profesión. Afrontaremos cómo puede realizarse dicha investigación, cómo ba de obtenerse, y, en último término, qué alcance puede tener; esto es, cuáles pueden ser sus consecuencias, y qué valor probatorio pueden tener sus informes en el marco de un proceso. Todo ello con el propósito de enmarcar la investigación privada en las exigencias derivadas del texto constitucional de respeto de los derechos fundamentales, partiendo de su eficacia tanto vertical, como horizontal; ya que la actuación de los detectives, cada vez más demandada, incide sobre derechos que son nucleares, señaladamente, la protección del domicilio, el secreto de las comunicaciones, así como los derechos al honor, a la intimidad, a la propia imagen, y a la protección de datos de carácter personal.

KEY WORDS: private investigation, fundamental rights, evidential value their reports.

PALABRAS CLAVE: investigación privada, derechos fundamentales, valor probatorio de sus informes.

FECHA DE RECEPCIÓN: 26.12.2020

FECHA DE ACEPTACIÓN: 26.01.2021 
